\title{
Paradoxos da "identidade nacional" nos discursos arquitetônicos de Lucio Costa e Sylvio de Vasconcellos
}

Paradoxes of Brazilian "national identity" in the architectural speeches of Lucio Costa and Sylvio de Vasconcellos

https://doi.org/10.1590/1982-02672020v28e14

\section{DIEGO NOGUEIRA DIAS'}

http:/ / orcid.org/0000-0002-1320-9845

Universidade Federal do Rio de Janeiro / Rio de Janeiro, RJ, Brasil

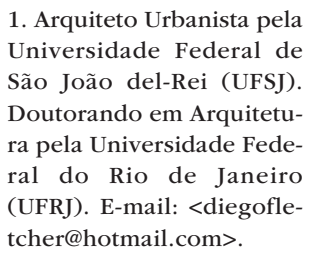

Urista pela versidade Federal de Doutorando em Arquitetura pela Universidade Fede(UFRJ). E-mail: <diegofletcher@hotmail.com>.
RESUMO: No debate em torno do período e do estilo arquitetônico que representassem a identidade nacional na historiografia da arquitetura brasileira, nas primeiras décadas do século $X X$, diferentes agentes tomaram lugar na consolidação do ideário patrimonial arquitetônico. Figuras marcantes às políticas de preservação cultural, tais como Rodrigo Melo Franco de Andrade e Mário de Andrade, integraram o espaço público ressaltando suas posições de intelectuais inerentes às políticas culturais. Tendo em vista tal fato, este artigo se debruça sobre a consolidação no imaginário social da arquitetura setecentista enquanto efetiva representação da arquitetura nacional, concretizando-se enquanto estilo/ período com o maior número de edificações tombadas até 1970. Compreendendo os diferentes sujeitos envolvidos nesse processo, centra-se, assim, na efetiva ação política de Lucio Costa e Sylvio Vasconcellos na defesa em torno do patrimônio colonial, a partir de textos e intervenções nas cidades tombadas Brasil afora, conformando e consolidando suas estratégias em torno de um ideário de patrimônio e nação. Além disso, busca-se compreender a relação direta estabelecida por ambos os agentes entre a arquitetura "eleita" patrimônio nacional e os preceitos do novo fazer arquitetônico vinculado ao Movimento Moderno, ao qual eram adeptos. Justificando o novo a partir do primitivo, numa relação perfeita em que tudo se explica e se encaixa, a arquitetura eclética foi tratada como cópia de estilos, 
exacerbação de ornamentos e vinculação ao estrangeirismo, se opondo assim ao projeto de nação pleiteado. Devemos sempre rever conceitos e diretrizes, tratando de forma mais verdadeira e justa o nosso patrimônio eclético, e em consequência, nossa historiografia arquitetônica.

PALAVRAS-CHAVE: Identidade nacional. Lucio Costa. Sylvio de Vasconcellos. Arquitetura colonial. Movimento Moderno.

ABSTRACT: In the debate about the period and the architectural style that represented the national identity in the historiography of Brazilian architecture, in the first decades of the twentieth century, different agents took place in the consolidation of the architectural heritage idea. Important characters in cultural preservation policies, such as Rodrigo Melo Franco de Andrade and Mário de Andrade, integrated the public space emphasizing their positions of organic intellectuals in cultural policies. Given this fact, this article focuses on the consolidation in the social imaginary of eighteenth-century architecture as an effective representation of national architecture, consolidating itself as a style/ period with the largest number of buildings listed until 1970. Understanding the different subjects involved in this process, this article focuses on the effective political action of Lucio Costa and Sylvio Vasconcellos on the defense of colonial heritage, based on texts and interventions in the overturned cities throughout Brazil, shaping and consolidating their strategies around an ideology of heritage and nation. In addition, we seek to understand the direct relationship established by both agents between the "elected" national heritage architecture and the precepts of the new architectural practice linked to the Modern Movement, to which they were adherents. Justifying the new from the primitive, in a perfect relationship where everything can be explained and fitted, the eclectic architecture was treated as a copy of styles, exacerbation of ornaments and link to foreignism, in opposition at the claimed nation project. We should always review concepts and guidelines, dealing more truthfully and fairly with our eclectic heritage, and consequently with our architectural historiography.

KEYWORDS: National identity. Lucio Costa. Sylvio de Vasconcellos. Colonial architecture. Modern movement. 
As construções em estilo eclético foram amplamente criticadas por escritores, pensadores e arquitetos brasileiros, especialmente a partir da década de 1920. A experiência do ecletismo no âmbito nacional foi vista por diversas gerações como mera reprodução de estilos arquitetônicos inseridos no passado europeu. Mário de Andrade, Monteiro Lobato, entre outros, em diversas de suas obras se posicionaram contra o que consideravam a "cidade europeia" no Brasil. Defendiam a arquitetura barroca mineira como a verdadeira representante do caráter nacional. Frente a ela, as construções de inspiração europeia se tornavam inadequadas para o cenário tropical. Para esses modernos, que influenciaram a primeira fase de atuação do Instituto do Patrimônio Histórico e Artístico Nacional (Iphan) (chamada de heroica, como será visto adiante), apenas a arquitetura do período colonial deveria ser considerada patrimônio digno de preservação.

Mário de Andrade, então, em 1936, por encomenda do ministro da Educação Gustavo Capanema, elaborou o anteprojeto para criação de um serviço de patrimônio no Brasil. No ano seguinte, a 30 de novembro, é criado o Decreto-Lei 25/1937, organizando a proteção do patrimônio histórico e artístico nacional e regulamentando o mecanismo do tombamento no país. Capanema nomeou Rodrigo Melo Franco de Andrade, advogado, escritor e jornalista para dirigir o lphan em um momento marcante tanto para as artes - com o Movimento Moderno, ao qual os intelectuais que criaram o órgão eram adeptos -, quanto para a política - com a instauração do Estado Novo, em 1937, e o início da ditadura de Getulio Vargas, quando o Estado passou a ser o representante legítimo dos interesses da nação, entendido como indivíduo coletivo. ${ }^{2}$

As políticas implantadas inicialmente pelo Iphan foram centradas no tombamento e na criação de uma revista que desse visibilidade e respaldo à nova secretaria. Assim, ainda em 1937, com a promulgação do decreto-lei, criaram-se os quatro livros do tombo, nos quais começaram a se registrar os bens que iam sendo objeto de tombamento. A criação de uma revista do órgão, segundo Márcia Regina Romeiro Chuva, ${ }^{3}$ visava, a partir do debate entre intelectuais e protagonistas da instituição, por meio de notícias, artigos e polêmicas na grande imprensa, somado ao caráter legitimador e divulgador de um "conhecimento especializado prescrito pela agência do Estado", uma forma de proteção do patrimônio brasileiro. Adotada como prioridade nos tombamentos, a produção colonial brasileira, considerada "manifestação de uma autêntica tradição nacional"4 foi, através da revista do Iphan, perpetuada como legitimamente brasileira. Como Aponta Flavia Brito do Nascimento, "a relação entre materialidade e escrita da história esteve lado a lado das justificativas por proteções legais dos bens selecionais [para 
5. Nascimento (2016, p. 123).

6. Ibid.

7. Cf. Castriota (2009).

8. Cf. Chuva (2009).

9. Cf. Micelli (1987).

10. Cf. Fonseca (2005). tombamento]". 5 Assim, "a história da arquitetura era operacionalizada também por meio das fontes (no caso bens culturais) disponibilizadas às gerações futuras". 6

Leonardo Castriota ${ }^{7}$ destaca que, nos primeiros tombamentos empreendidos pelo Iphan, o valor artístico de um bem era ressaltado como justificativa necessária a seu tombamento, muito mais do que o valor histórico do conjunto, sua trajetória e acontecimentos configuradores de um espaço socialmente construído. Dessa forma, os valores da arte e da estética sobrepuseram-se de maneira extrema sobre a história e as relações estabelecidas no meio urbano.

espaço editorial do Iphan - a "menina dos olhos de Rodrigo", como disse Lucio Costa - era sem dúvida, "um lócus de ação bastante distinto", quando comparado à área técnico-administrativa e ao Conselho Consultivo. ${ }^{8}$ Ali eram divulgados os ideais dos intelectuais do órgão e as diretrizes que desejavam consolidar nas cidades e monumentos históricos, e, acima de tudo, na população. Sérgio Micelli` aponta que a criação do órgão, importante capítulo da história intelectual e institucional da geração moderna, foi um passo decisivo da intervenção governamental no campo da cultura, e o lance acertado de um regime autoritário empenhado em construir uma "identidade nacional".

A estrutura montada na capital federal, então Rio de Janeiro, constituiu um corpo técnico com nomes como Alcides da Rocha Miranda, Carlos Drummond de Andrade, José de Souza Reis, Lucio Costa, Luís Saia, Mário de Andrade, Paulo Thedim Barreto, Renato Soeiro, entre outros. Costa, que manter-se-ia à frente da Divisão de Estudos e Tombamento do Iphan do momento de sua criação até aposentar-se, em 1972, teve função decisiva na definição dos critérios de seleção dos monumentos a serem legalmente preservados, bem como em intervenções em obras de restauração.

Em sua análise da história do Iphan, Maria Cecília Londres Fonseca ${ }^{10}$ divide a atuação do órgão entre suas fases "heroica" (1937-1967) e "moderna" (1967-1979). A fase heroica abrange a permanência de Rodrigo Melo Franco de Andrade como presidente do órgão e foi a mais árdua em termos de trabalho, tendo em vista a complexidade na criação de uma rede de tarefas até então inédita no país: estabelecer as diretrizes, formar e qualificar uma equipe e realizar o levantamento e seleção de obras em um país de tamanho continental certamente não seria tarefa fácil. Luís Saia, um dos primeiros técnicos regionais do serviço, esclareceu em depoimento os objetivos iniciais e os três principais pontos acertados do projeto de salvaguarda do patrimônio brasileiro:

a) inventariar o que existia de amostragem mais significativa da formação brasileira;

b) socorrer urgente, e salvar alguns monumentos que estavam profundamente atingidos pela ruína e ameaçavam perecimento completo; 
c) introduzir na normalidade nacional, inclusive e principalmente no campo jurídico, não apenas a figura do "tombamento" e suas consequências, especialmente aquelas que representavam algum gravame caindo sobre a propriedade privada.

[...] colocar corajosamente em segundo plano tudo o que pudesse ser feito mais tarde, com mais experiência e mais gente: controle do comércio de arte, tombamento paisagístico, inventário de artes menores, aproveitamento e revalorização de monumentos cuja função se tornara obsoleta, tombamento de conjuntos urbanos, etc. "1

Cabe destacar o instrumento mais importante citado por Saia, o tombamento. De acordo com Cêça Guimaraens,

O [...] tombamento representa o ato de inscrever os bens de natureza material e imaterial, portadores de referência à identidade, à nação e à memória dos diferentes grupos formadores da sociedade brasileira, tomados individualmente ou em conjunto, em um dos Livros de Tombo do Iphan, ou da forma apropriada às prescrições das instâncias estaduais e municipais competentes. ${ }^{12}$

De fato, o tombamento "mantinha o direito de propriedade dentro dos moldes estabelecidos pela Constituição de 1934, isto é, submetendo o individual ao coletivo". ${ }^{13}$ Este se tornou o instrumento que consolidaria a visão de um tempo e de uma história eleitos como aqueles válidos para o do país. Minas Gerais, considerada um dos maiores berços da nacionalidade, teve prioridade na proteção dos conjuntos, sobrepondo-os aos bens isolados, pelo caráter de ambiência homogênea que apresentava até então. $\bigcirc$ próprio Rodrigo Melo Franco de Andrade por vezes enfatizou que "a maior concentração dos monumentos que integram o patrimônio histórico e artístico nacional está localizada em Minas Gerais". ${ }^{14}$

Em 1946 passou a vigorar o Decreto-Lei 8.534, que reestruturou o Iphan. Márcia Chuva ${ }^{15}$ aponta que essa reformulação, após o fim do Estado Novo, visou estabelecer um controle mais rígido das ações empreendidas pelo órgão, institucionalizando procedimentos. Além da sede do órgão no Rio de Janeiro e sua diretoria geral, conformaram-se quatro distritos: $1^{\circ}$ Distrito sediado em Recife, abrangendo os estados de Pernambuco, Paraíba, Rio Grande do Norte e Alagoas; $2^{\circ}$ Distrito, com sede em Salvador, acumulando os estados da Bahia e de Sergipe; $3^{\circ}$ Distrito, sediado em Belo Horizonte e correspondendo a Minas Gerais; e $4^{\circ}$ Distrito, sediado em São Paulo e abrangendo além deste, Paraná, Santa Catarina e Rio Grande do Sul. A importância do patrimônio mineiro é mais uma vez salientada, sendo o único além do distrito sede composto por apenas um estado.
11. Saia (1980, p. 17).

12. Guimaraens (2002, p $60)$.

13. Reis (2012, p. 114).

14. Andrade (1969, p. 11) O texto é resultado da palestra proferida por Andrade em Ouro Preto em $1^{\circ}$ de julho de 1968, no aniversário de 257 anos da elevação da localidade à categoria de Vila e está transcrito na $R e$ vista do Patrimônio Histórico Artístico Nacional n. 17.

15. Cf. Chuva (2009). 
Às duas divisões, de Estudos e Tombamento e de Conservação e Restauração, subordinavam-se à seção de Arte e de História e à de Projetos e Obras, respectivamente (figura 1). A seção de Projetos e Obras tinha foco nas reparações e restaurações dos bens e conjuntos tombados no Brasil, e será importante nas intervenções que serão explicitadas a seguir. Ainda de acordo com Chuva, ${ }^{16}$ este era o setor que mais recebia verbas, mesmo que escassas.

\section{Diretoria do Patrimônio Histórico e Artístico Nacional}

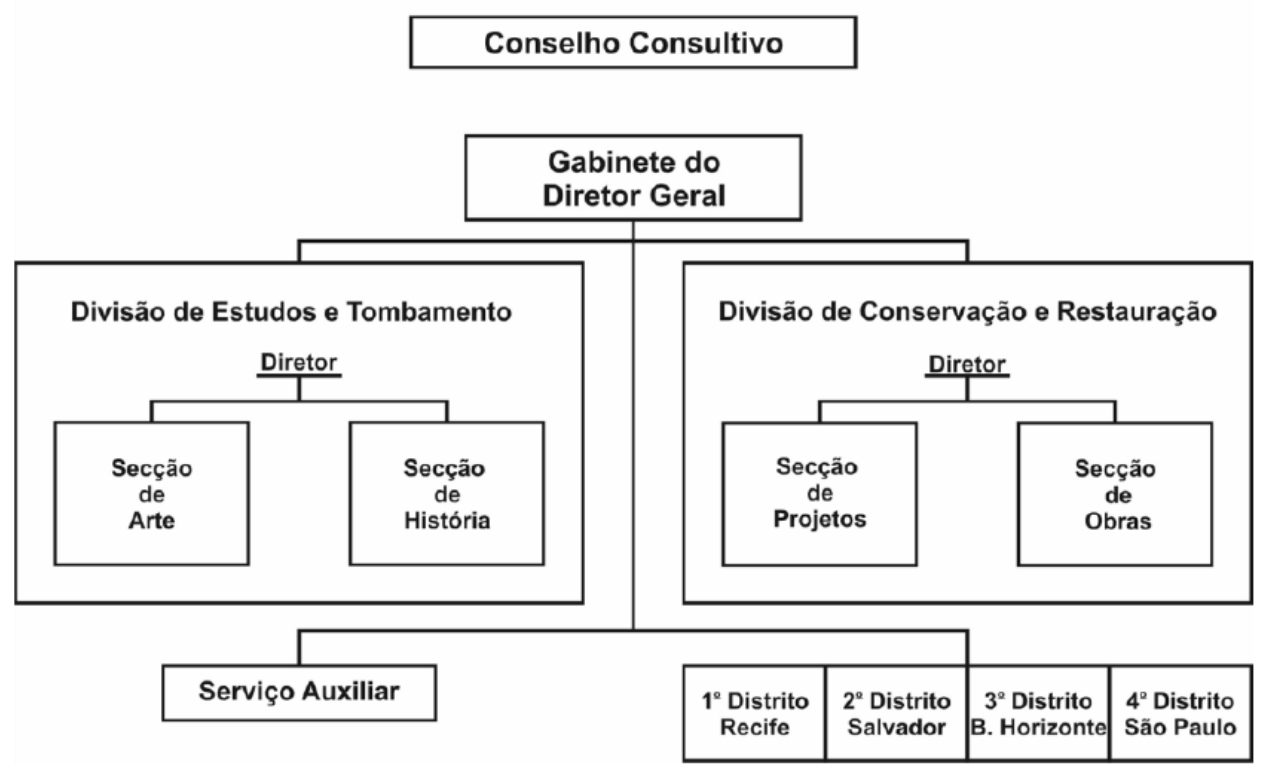

Figura 1 - Organograma do Iphan a partir de 1946. Fonte: Reis, 2012, p. 120.

Já em 1967, portanto, em sua fase "moderna", com a aposentadoria de Andrade, assumiu a presidência do Iphan Renato de Azevedo Duarte Soeiro, que ocupou o cargo até 1979. Este período foi marcado pela atuação voltada aos museus e casas históricas, como apresentado na Portaria n. 230, de 26 de março de 1976. Também se destacam os grandes impasses ocorridos nessa época na preservação dos conjuntos e edificações históricas, pois o Brasil passava por "modernizações" que provocavam certa repulsa da população em geral pelo velho e tradicional.

Maria Cecília Fonseca ressalta que era iminente ao Iphan "demonstrar que os interesses da preservação e os do desenvolvimento não são conflitantes, pelo contrário, são compatíveis". ${ }^{17} \bigcirc$ turismo então se configuraria como pontochave entre o valor cultural e o econômico nas cidades. Desse período cabe destacar o Compromisso de Brasília, documento aprovado em um encontro de diversos setores estaduais e municipais em Brasília, em 1970, que objetivou "a 
extensão da responsabilidade pela proteção dos bens culturais de valor regional aos Estados e Municípios", 18 descentralizando e dividindo, de certa forma, a tarefa da proteção patrimonial num país de tamanho continental.

\section{NARRATIVAS ORTODOXAS: COLONIAL E MODERNISTA}

Ao analisar a história do Iphan, pode-se perceber o total direcionamento da política oficial de proteção do patrimônio em torno das arquiteturas colonial e modernista. Até a década de 1970, das 600 edificações tombadas no país, 529 eram do período colonial. Silvana Rubino afirma que nos primeiros anos de atuação do órgão:

O país que foi passado a limpo formando um conjunto de bens móveis e imóveis tombados tem lugares e tempos privilegiados. Este conjunto documenta fatos históricos, lugares hegemônicos e subalternos, mapeando não apenas um passado, mas o passado que essa geração tinha olhos para ver e, assim, deixar como legado.

[...] o SPHAN desenvolveu suas atividades de modo marcadamente desigual. O conjunto dos bens tombados desenha um mapa de densidades discrepantes nas diversas regiões, períodos e tipos de bens, formando conjuntos fechados e finitos. ${ }^{19}$

A ênfase em traçar uma linha direta - entre o colonial e a nova arquitetura modernista - sobre a história da arquitetura brasileira era tão marcante que projetos modernistas foram tombados antes mesmo de estarem suas obras concluídas, como a lgreja de São Francisco de Assis, na Pampulha, em Belo Horizonte, ou poucos anos após sua construção, a exemplo do antigo prédio do Ministério da Educação, no Rio de Janeiro.

Antoine Compagnon, a respeito da interpretação dos modernistas sobre o passado colonial, e sua exata correlação com a "nova arquitetura", estabelece as "narrativas ortodoxas", 20 escritas sempre "em função do desfecho ao qual querem chegar [...] e que serve para legitimar uma arte contemporânea que, no entanto, quer estar em ruptura com a tradição". ${ }^{21}$ Verdadeiro paradoxo.

Junto a Lucio Costa, outro personagem configura-se, assim, como peça-chave nessa inter-relação século XVIII-século XX: Sylvio de Vasconcellos. Seus textos, Documentação Necessária (1937) e Construções Coloniais em Minas Gerais
20. Compagnon (1996, p. 44).

21. Castriota (2009, p. 139140). 
22. Costa (1937, p. 31).

23. Ibid., p. 31-32.

(1956), respectivamente, em conjunção às suas atuações individuais, expõem quase que de forma irrefutável a historiografia da arquitetura que visavam consolidar.

\section{O PURISMO ARQUITETÔNICO DE LUCIO COSTA NA PATRIMONIALIZAÇÃO DO "ESTILO" NACIONAL}

Em seu texto Documentação Necessária, ainda em 1937, na primeira edição da Revista do Serviço do Patrimônio Histórico e Artístico Nacional, Lucio Costa caracteriza a arquitetura da Colônia recém-descoberta pelos portugueses como algo novo, a partir da adaptação das técnicas conhecidas a um novo ambiente:

Ora, a arquitetura popular apresenta em Portugal, a nosso ver, interesse maior que a "erudita" [...] É nas suas aldeias, no aspecto viril das suas construções rurais a um tempo rudes e acolhedoras, que as qualidades da raça se mostram melhor. Sem o ar afetado e por vezes pedante de quando se apura, aí, a vontade, à vontade ela se desenvolve naturalmente adivinhando-se na justeza das proporções e na ausência de "make-up", uma saúde plástica perfeita - se é que podemos dizer assim.

Tais características, transferidas - na pessoa dos antigos mestres e pedreiros "incultos" - para a nossa terra, longe de um mau começo, conferiram, desde logo, pelo contrário, à arquitetura portuguesa na colônia, esse ar despretensioso e puro que ela soube manter, apesar das vicissitudes por que passou, até meados do século XIX. ${ }^{22}$

E vai além, ao destacar a ausência de maneirismos e exageros presentes na arquitetura portuguesa, colocando as construções brasileiras como superiores:

Sem dúvida, neste particular se observa o "amolecimento" notado por Gilberto Freyre, perdendo-se, nos compromissos de adaptação ao meio, um pouco daquela "carrure" tipicamente portuguesa; mais em compensação, devido aos costumes mais simples e à largueza maior da vida colonial, e por influência, também, talvez, da própria grandiosidade do cenário americano, - certos maneirismos preciosos e um tanto arrebitados que lá se encontram, jamais se viram aqui. ${ }^{23}$

Em referência à morada tradicional brasileira, em seus primórdios, ele explicita que

A nossa casa se apresenta assim, quase sempre, desataviada e pobre [...]. Contudo, afirmar-se que ela nenhum valor tem, como obra de arquitetura, é desembaraço de expressão que não corresponde, de forma alguma, à realidade. 
Haveria, portanto, interesse em conhecê-la melhor, não propriamente para evitar a repetição de semelhantes leviandades ou equívocos - que seria lhes atribuir demasiada importância -, mas para dar aos que de tempos a esta parte se vêm empenhando em estudar de mais perto tudo que nos diz respeito, encarando com simpatia coisas que sempre se desprezaram ou mesmo procuraram encobrir, a oportunidade de servir-se dela como material de novas pesquisas $[\ldots]^{24}$

Nota-se aqui a paixão e a predileção de Costa pela arquitetura do século XVIII, ao enfatizar que os arquitetos modernos deveriam buscar nas moradias do período as bases para a arquitetura de sua época, sem, entretanto, reproduzilas ipsis litteris.

Ainda em Documentação Necessária, ao consolidar o colonial e a arquitetura modernista como complementares, Costa critica o neocolonial - movimento ainda vigente, sob o qual havia se formado -, por considerá-lo um "artificioso processo de adaptação" 25 visando resgatar "os elementos já sem vida da época colonial". ${ }^{26} \bigcirc$ Movimento Moderno seria a continuação da "boa tradição", seria "a evolução que estava normalmente se processando", ${ }^{27}$ evolução esta que teria sido interrompida pelo neocolonial. A esse respeito, ressalta: "fingir por fingir, que ao menos se fingisse coisa nossa. E a farsa teria continuado - não fora o que sucedeu" . 28 Para o arquiteto e chefe do Iphan, a morada colonial, com sua "justeza de proporções" 29 e "saúde plástica perfeita" 30 deveria constituir-se como base para os arquitetos contemporâneos.

No artigo da primeira edição da Revista do Patrimônio, além de instituir seus preceitos acerca da preservação e de qual modelo arquitetônico merecia ser preservado, Costa coloca o mestre de obras como personagem essencial no saber-fazer dessa arquitetura. Associa o trabalho prático e funcional que o pedreiro adota na composição da casa como "um processo evolutivo em direção aos princípios genéticos do Movimento Moderno". ${ }^{31}$

Rodrigo Baeta, na relação da "evolução linear" da arquitetura estabelecida por Lucio Costa, ressalta:

[...] o incremento gradativo da fenestração na fachada das residências no sentido do ritmo horizontal, por exemplo, vai incondicionalmente derrocar na janela rasgada "ao longo" - quarto ponto da arquitetura de Le Corbusier - confirmando o mecanismo de desenvolvimento da arquitetura pregado por Costa. ${ }^{32}$

Ao que Costa chama de "evolução" ${ }^{33}$ da arquitetura (figura 2), entre relação de aberturas e os mestres de obras, dita
24. Ibid., grifo nosso.

25. Ibid., p. 39.

26. Ibid.

27. Ibid., p. 35.

28. Ibid., p. 39.

29. Ibid., p. 31

30. Ibid.

31. Baeta (2003, p. 41).

32. Ibid.

33. Costa (1937, p. 35). 
Nas casas mais antigas, presumivelmente nas do século XVI e durante todo o século XVII, os cheios teriam predominado, e logo se compreende por quê; à medida, porém, que a vida tornava mais fácil e mais policiada, o número de janelas ia aumentando; iá no século XVIII, cheios e vazios se equilibram, e no começo do século XIX, predominam francamente os vazios; de 1850 em diante as ombreiras quase se tocam, até que a fachada, depois de 1900, se apresenta praticamente toda aberta, tendo os vãos, muitas vêzes, ombreira comum. O que se observa, portanto, é a tendência evidente para abrir sempre e cada vez mais [...] Verifica-se, assim, portanto, que os mestres de obras estavam, ainda em 1910, no bom caminho. Fiéis à boa tradição portuguêsa de não mentir, êles vinham aplicando, naturalmente, às suas construções meio feiosas tôdas as novas possibilidades da técnica moderna, como, além das fachadas quase completamente abertas, as colunas finíssimas de ferro, os pisos de varanda armados com duplo Te abobadilhas, as escadas também de ferro, sôltas e bem lançadas $[\ldots]^{34}$
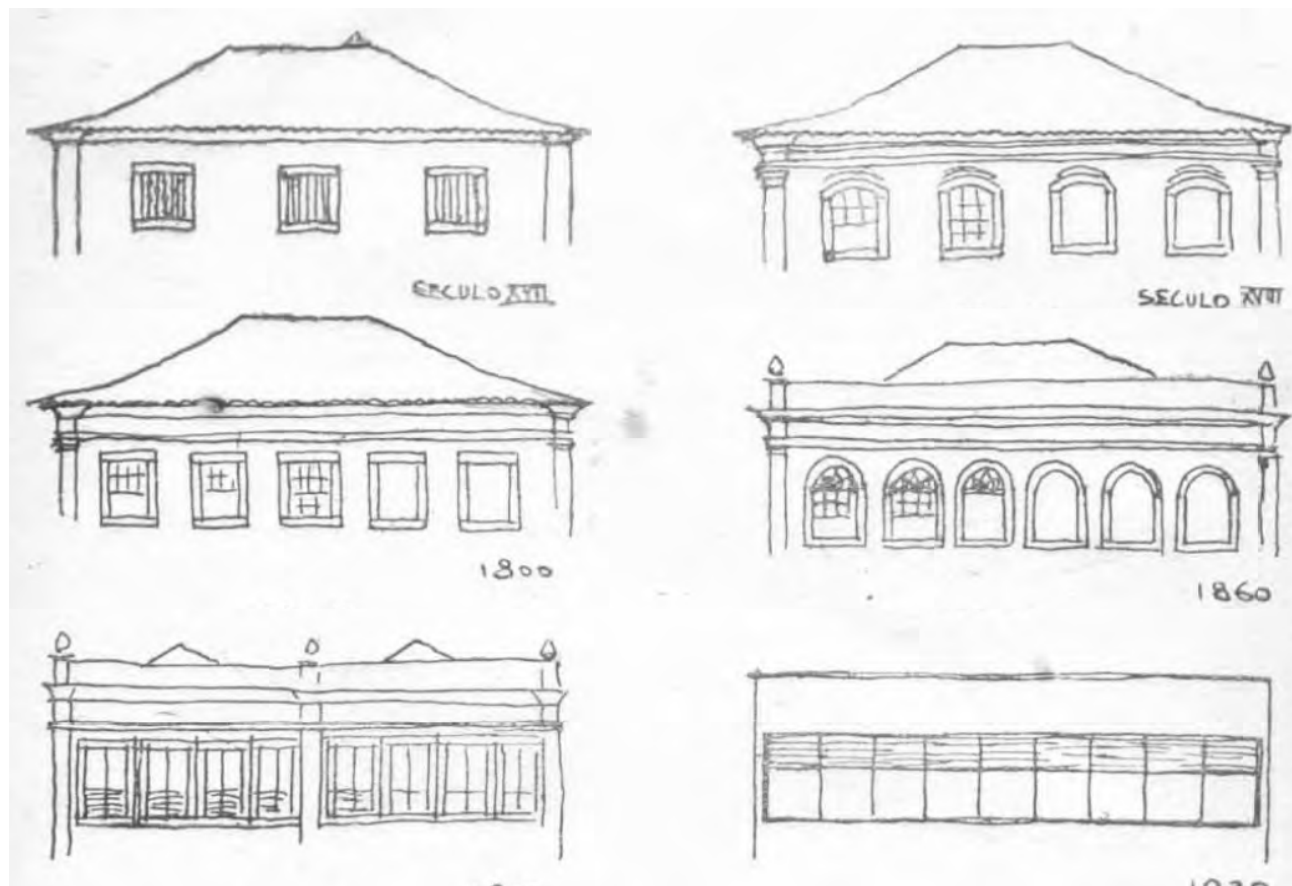

1900

1930

Figura 2 - Croquis de Lucio Costa exemplificando o que chamou de "evolução" dos vãos das edificações. Fonte: Costa, 1937, p. 36-37. Modificado pelo autor.

Nota-se a ausência da composição neocolonial no desenho de Costa, talvez em função de firmar o Movimento Moderno e apagar o considerado "equívoco" do movimento precursor. $\bigcirc$ arquiteto conclui assim que a arquitetura modernista, num ato comum "evolucionista", que não foi captado pelo ecletismo, absorveu o aprendizado do colonial e, além disso, consolidou não só o fazer arquitetônico de seu tempo, mas a correta conexão deste com o passado. Marcelo Puppi aponta que o texto em análise 
"pretende determinar o caminho correto para a pesquisa histórica em arquitetura no país e, conseqüentemente, a política correta de preservação do patrimônio". ${ }^{35}$

Na política de Lucio Costa, podem ser consideradas três ações principais visando consolidar o projeto de nação brasileira: a salvaguarda da arquitetura colonial existente; a remodelação da arquitetura considerada espúria, de modo a integrá-la à paisagem; e a consolidação da "nova arquitetura" moderna. ${ }^{36}$ Neste artigo nos ateremos aos dois primeiros itens, por sua complexidade e necessidade de reflexão detalhada.

\section{Salvaguarda da arquitetura colonial existente}

Assumindo a direção da Divisão de Estudos e Tombamento (DET), logo no primeiro ano da criação do Iphan,

[...] talvez Lucio Costa tenha sido o único a participar das três instâncias de entesouramento do passado nacional (que trazem embutidas instâncias de esquecimento): arquiteto intelectual mas também funcionário estável, ele elegeu o que tombar, como cuidar da obra tombada e como explicar e situar a obra tombada, assim como aquela que não merecia tal inscrição. Nesse sentido, talvez até mais do que Mário ou Rodrigo, Lucio tenha encarnado o papel de intelectual total e polivalente do Sphan e certamente muitas das chaves de entendimento das premissas que orientaram a tradução do vago decreto num conjunto de bens tombados estejam em sua abrangente atuação. ${ }^{37}$

Estes quatro Livros do Tombo instituídos no Decreto-Lei n. 25 (História, Belas-Artes, Artes Aplicadas e Arqueológico, Etnográfico e Paisagístico) ${ }^{38}$ registraram os tombamentos que centraram-se inicialmente nos estados do Rio de Janeiro, Bahia, Pernambuco e Minas Gerais, totalizando, até 1945, 386 bens. $\bigcirc$ preconizado no anteprojeto de Mário de Andrade foi substancialmente alterado no decreto, consolidando o "patrimônio de pedra e cal". Enquanto Rodrigo Melo Franco de Andrade enfatizava o critério histórico ${ }^{39}$ do patrimônio em seus textos, Lucio Costa contrabalanceava a favor do critério artístico.

Como aponta Silvana Rubino "o período histórico de eleição para os tombamentos do Sphan situa-se entre os séculos XVI e XVIII, sendo o período entre - XIX e o término da Primeira República o oposto disso". ${ }^{40}$ Quando coubesse tombamento a um bem do século XIX, em ato raro, justificava-se por seu caráter excepcional, apesar de ser deste século. Ao ser inscrito em um dos Livros do Tombo, "o bem passa a fazer parte do modelo reduzido de um país imaginado". ${ }^{41}$
35. Puppi (1998, p. 23).

36. Tais itens podem ser mais bem compreendidos a partir do Plano Especial de Ouro Preto, redigido por Lucio Costa em março de 1958, em sua atuação no Instituto do Patrimônio Histórico e Artístico Nacional, cujo documento encontra-se disponível em Barel Filho (2013, p. 90-91).

37. Rubino (2002, p. 9).

38. "Categorias assim definidas pelo Decreto-Lei $\mathrm{n}^{\circ}$. 25: $1^{\circ}$ ) no livro do Tombo Arqueológico, Etnográfico e Paisagístico, as coisas pertencentes às categorias de arte arqueológica, etnográfica, ameríndia ou popular [...]; $2^{\circ}$ ) no livro do Tombo Histórico, as coisas de interesse histórico e as obras de arte histórica; $3^{\circ}$ ) no livro do Tombo das Belas-Artes, as coisas de arte erudita nacional ou estrangeira; $4^{\circ}$ ) no livro do tombo das Artes Aplicadas, as obras que se incluem na categoria das artes aplicadas, nacionais ou estrangeiras" (Rubino, 2002, p. 10).

39. Alguns textos em que o critério histórico é ressaltado por Andrade: "Brasil: Monumentos Históricos e Arqueológicos" e "Apontamentos para a história da arte no Brasil: a pintura mineira anterior a 1750 ".

40. Rubino (2002, p. 14).

41. Rubino (1996, p. 98). 
42. Ibid., p. 98.

43. Cf. Costa (1972).

44. Ibid.

45. Cf. Costa (1978).
Minas Gerais, cuidada pessoalmente por Andrade, filho da terra, consolidou 165 bens em sua época de presidente do órgão. Destes, 96 do século XVIII. $\bigcirc$ levantamento de Rubino (1996) apresentado na tabela 1 ressalta:

O conjunto eleito revela o desejo por um país passado, com quatro [cinco] séculos de história, extremamente católico, guardado por canhões, patriarcal, latifundiário, ordenado por intendências e casas de câmara e cadeia, e habitado por personagens ilustres, que caminham entre pontes e chafarizes. ${ }^{42}$

Tabela 1 - Bens tombados pelo Iphan entre 1938 e 1967 de acordo com sua data de construção. Fonte: Rubino, 1996, p. 102.

\begin{tabular}{|l|l|l|}
\hline \multicolumn{1}{|c|}{ Século } & \multicolumn{1}{c|}{$N^{\circ}$} & \\
\hline Sem data precisa & 36 & 5,2 \\
\hline$X V I$ & 45 & 6,5 \\
\hline$X V I I$ & 101 & 14,7 \\
\hline$X V I I I$ & 377 & 54,7 \\
\hline$X I X$ & 124 & 18,0 \\
\hline$X X$ & 6 & 0,9 \\
\hline Total & 689 & 100,00 \\
\hline
\end{tabular}

Essa eleição pode ser atribuída diretamente a Lucio Costa, ao aceitar ou negar pareceres de tombamento à frente da DET, sem repressão ou questionamento algum. Ressalta-se também os pareceres de tombamento emitidos pelo arquiteto em favor de edifícios modernistas e contra edificações ecléticas, como o parecer a favor do tombamento da Igreja de São Francisco de Assis, projeto de Oscar Niemeyer, na Pampulha, em Belo Horizonte, mesmo antes do edifício estar concluído. Ou do parecer contrário ao tombamento do antigo prédio do Ministério da Agricultura, no Rio de Janeiro (1978), construído em 1922, projeto do arquiteto Adolfo Morales de Los Rios, o qual considerava "almanjorra de concreto, coroada por uma cúpula, situada entre o cais e a esplanada do Castelo [... ] e que já nasceu bastarda [0] para a Exposição de 1922". ${ }^{43}$ "Por sua falta de estilo por sua desproporção, por sua feiúra congênita" 44 Costa concluía que "o bem não possui atributos necessários para inclusão no acervo histórico e artístico da nação". ${ }^{45}$ 


\section{Remodelação da arquitetura "espúria"}

"O purismo que Costa persegue o impede de compreender o ornamento como elemento indissociável da arquitetura". ${ }^{46}$ Em uma espécie de guerra contra os ornatos sem função estrutural, Lucio Costa inicia sua atuação na homogeneização principalmente das cidades tombadas na primeira leva do Iphan, de modo a configurar conjuntos "íntegros".

Nesse aspecto, o caso mais elucidativo envolvendo o arquiteto é o do edifício do Liceu de Artes e Ofícios de Ouro Preto (figura 3). Edificado sob os preceitos da arquitetura eclética, sofreu posteriormente intervenção orientada pelo arquiteto do Iphan, tornando-se modelo da homogeneização estilística almejada para as "cidades iphanianas" 47 em Minas Gerais. Faz-se pertinente, então, explicitar aqui seu histórico, do surgimento à mutilação, mutilação esta que logo se tornaria recorrente também em São João del-Rei.

Inaugurado em 25 de março de 1887, com muita pompa e presença do então presidente do estado Crispim Bias Fortes, ${ }^{48}$ em arquitetura eclética, o edifício do liceu contava com salas de aula e oficinas de prática visando a formação de jovens, em sua maioria de classe média baixa, para sua inserção qualificada no mercado de trabalho.

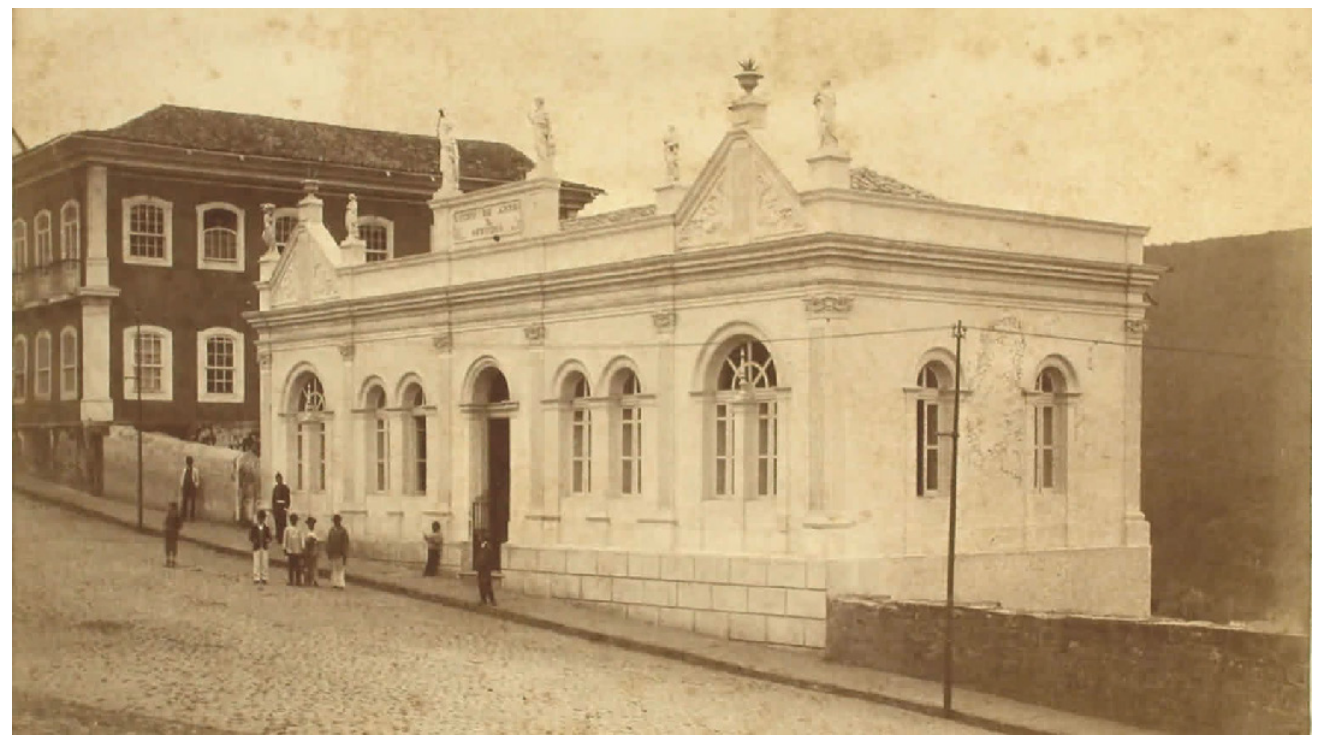

Figura 3 - Liceu de Artes e Ofícios de Ouro Preto em 1898. Foto de J. Brandi. Fonte: Arquivo Público Mineiro, s/d. Disponível em: <https://bit.ly/2jWdhOv>. Acesso em: 6 jun. 2019.
46. Baeta (2003, p. 39).

47. Guimaraens (2002, p. 191).

48. Cf. Silva (2009). 
49. Ibid., p. 87.

50. Ibid., p. 94.

51. Cf. Andrade ([s. d.]) In: Anjos (1998).

52. Cf. Silva, 2009.

53. Costa (1954a). Grifo nosso.

54. Costa (1954b). Grifo nosso.
Reafirmando "a figura do trabalhador como a essência da sua existência", ${ }^{49}$ a construção do edifício do Liceu "representou a efetivação da apropriação do ensino dos ofícios pelo aparato escolar". ${ }^{50} \bigcirc$ prédio serviu também como base para reuniões de grupos de trabalhadores e outras categorias sociais. Em 1906, passados 20 anos de sua inauguração, o liceu já contava com mais de 3.000 alunos matriculados, numa média de 163 por ano.

Com a consolidação do liceu na sociedade ouro-pretana, o corte do auxílio do estado a partir da segunda década do século XX associado ao desinteresse dos sócios em sua manutenção mergulharam a instituição em uma crise financeira em 1939. Estando o prédio em estado de arruinamento, um novo corpo de diretores, eleitos em 1946, buscou junto ao Iphan recursos para seu restauro, ao qual Rodrigo Melo Franco de Andrade em resposta, informa:

[...] apresso-me a escrever-the para prevenir que, embora tenha um grande empenho de corresponder ao seu desejo no sentido desta repartição contribuir para a conservação adequada da sede do Liceu, receio não estar habilitada, infelizmente, a servito no atual exercício financeiro, pela necessidade de aplicar todos os recursos disponíveis desta Diretoria em 1947 em obras que são reclamadas urgentemente em proveito de edifícios de valor histórico e artístico nos Estados do Norte. ${ }^{51}$

Esgotados os meios para salvar o liceu, seus sócios decidem por sua venda, que se deu em 26 de abril de 1953, a Vicente Ellena Tropia. ${ }^{52}$ A escolha do local para a construção do cinema inicia-se em uma edificação à rua São José, n. 29, posteriormente passando para um terreno vizinho ao liceu, e, enfim, adotando o edifício eclético do liceu. Assim, mesmo com parecer de José de Souza Reis constatando que o edifício já estava integrado com o ambiente e que intervir em sua forma poderia prejudicar ainda mais o conjunto, Lucio Costa posiciona-se: "Acho muito conveniente a demolição ou completa reforma do edifício do Lyceu. A construção ali do cinema, com aproveitamento do acentuado declive do terreno, daria ensejo a que se eliminasse a arquitetura bastarda desse edifício". ${ }^{53} \mathrm{E}$ continua:

Enquanto o arquiteto Souza Reis desaconselha qualquer alteração no prédio do Lyceu eu recomendo a sua demolição ou completa reforma pois ainda não se apagou da minha lembrança a impressão penosa que o edifício me causou, juntamente com o do Banco, quando conheci Ouro Preto em 1923.54 
Aqui nota-se a opinião pessoal do arquiteto sobre o edifício e o estilo que 55. Cf. Costa (1956). possuía como sendo o único motivo para a intervenção, e a completa ausência de embasamento teórico que a justificasse, assim como falta de coerência entre os próprios funcionários do orgão federal de preservação, adotando posições diametralmente opostas a respeito de atos de restauro. Tendo sidas iniciadas as obras do cinema a partir dos fundos, ficando a fachada para ser modificada por último, Costa encaminha então um parecer com anotações e um croqui de como deveria se adequar a frente do prédio (figura 4). Consta no parecer: "entendo que, feita obra no prédio, se deve procurar atenuar o seu aspecto bastardo eliminando-se os frontões e a platibanda e uniformizando-se os arcos". .55

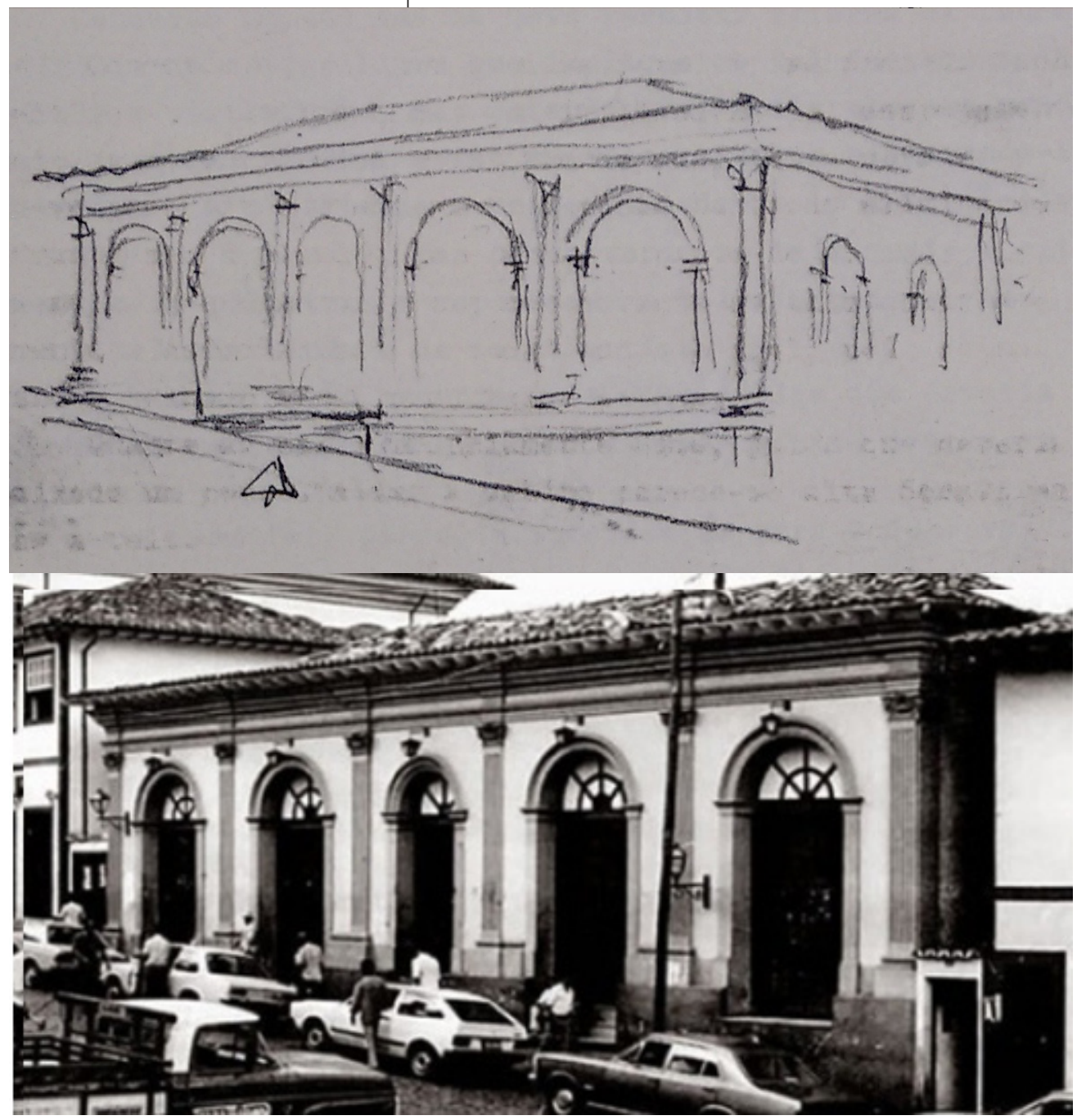

Figuras 4 e 5 - Croqui de Lucio Costa de 1956 para remodelação da fachada do Liceu, e o prédio após as obras, já como cinema, na década de 1980. Fontes: ACl/RJ - Série Obras, Caixa 0218, Pasta 0946; O Tempo, 2016. Disponível em: <https://bit.ly/2k1GN5c>. Acesso em: 6 mai. 2019. 


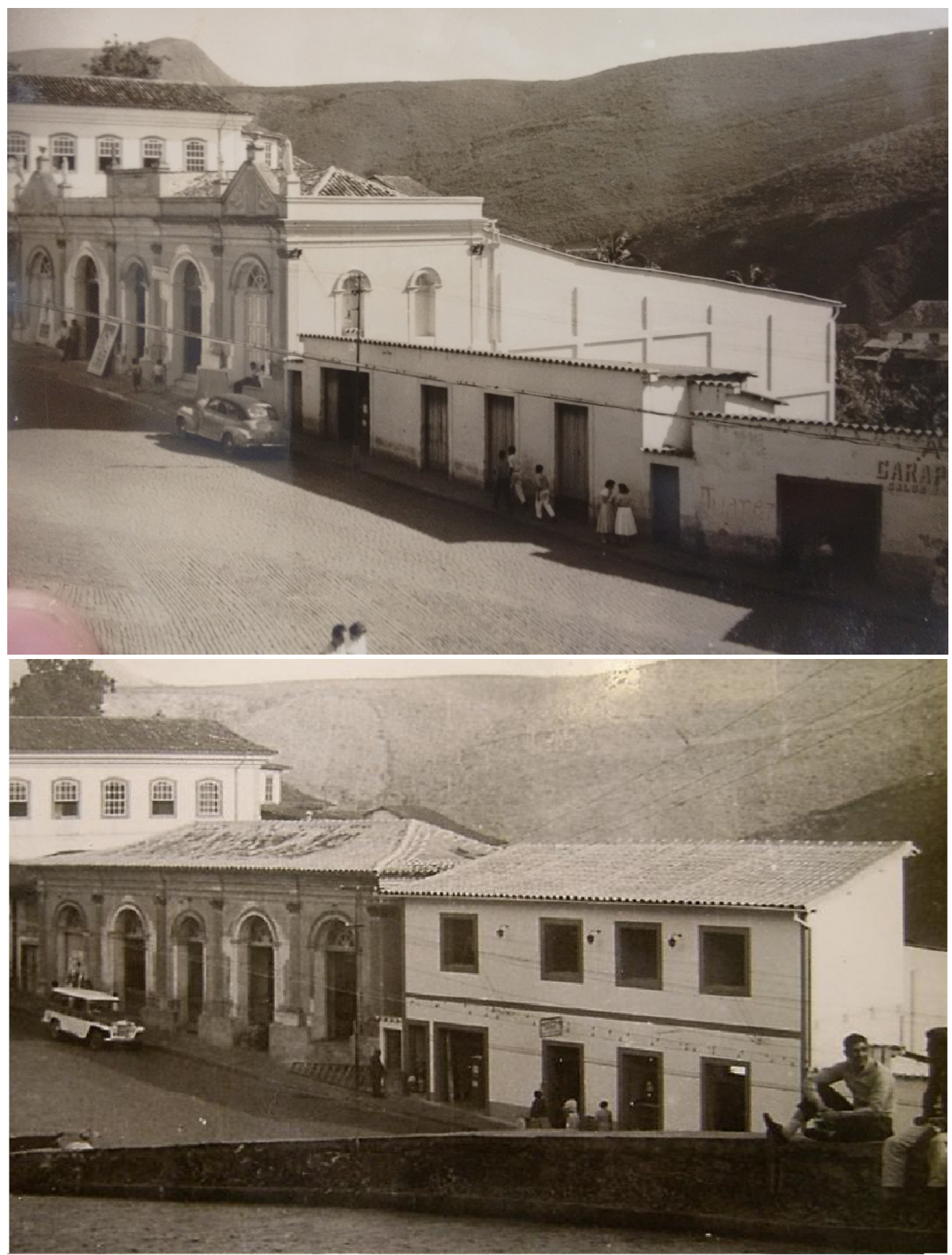

Figuras 6 e 7 - Prédio do Liceu em fase final das obras para cinema, com grande volume na parte posterior; e a solução encontrada por Vasconcellos com a construção de um segundo pavimento em estilo patrimônio na edificação vizinha, em 1959. Fonte: ACl/RJ - Série Obras, Caixa 0218 , Pasta 0946. 
A obra do cinema foi concluída em janeiro de 1959 e constituiu a fachada atual da edificação, tal como mostra a figura 5. Entretanto, o volume formado no alongamento da parte posterior da edificação causou grande impacto à paisagem ouro-pretana (figura 6), e os técnicos do Iphan, tentando amenizar este aspecto propõem diversas soluções, até Vasconcellos sugerir a construção de um segundo pavimento na edificação vizinha ao edifício do agora cinema. ${ }^{56}$ Incluída na lista de obras do Plano Especial de Ouro Preto, o resultado, um edifício de caráter pseudocolonial, ou melhor, em "estilo patrimônio", ${ }^{57}$ exposto na figura 7 , também se tornaria prática comum nos outros sítios mineiros tombados.

Há ainda outros exemplos de remodelações em edificações ecléticas de Ouro Preto como aquela ocorrida no Banco do Comércio, situado ao lado do Chafariz dos Contos, ou a do Fórum, na Praça Tiradentes, ou ainda a do Grupo Escolar Marília de Dirceu, todas envolvendo também a atuação de Costa, aconselhando e direcionando as atitudes do chefe do $3^{\circ}$ Distrito, Sylvio de Vasconcellos.

Os exemplos ouro-pretanos tornam clara a arbitrariedade nas intervenções para a definição de um núcleo histórico, que deveria ser "íntegro", não importando quão falso fosse. Servindo como modelo para as intervenções que viriam a seguir, foi ainda em 1954 (ano que Costa opina pela demolição ou remodelação do prédio do liceu) que ocorre a primeira das intervenções do Iphan sobre o ecletismo são-joanense. ${ }^{58}$

\section{SYLVIO DE VASCONCELLOS E A ARQUITETURA RESIDENCIAL}

Arquiteto do Patrimônio em Minas, Sylvio de Vasconcellos esteve à frente do cargo de chefe (que corresponde hoje ao de superintendente) do $3^{\circ}$ Distrito do Iphan entre 1939 e 1969, sendo o primeiro a ocupar tal posição no estado. Atuou veementemente em prol das cidades históricas mineiras e da preservação do legado setecentista do ciclo do ouro. Nascido em Belo Horizonte em 1916, Vasconcellos cursou o ginasial no Colégio Santo Antônio, em São João del-Rei, ${ }^{59}$ o que o possibilitou um contato direto com a arquitetura setecentista do país desde muito jovem.

Formou-se pela Escola de Arquitetura da Universidade Federal de Minas Gerais (UFMG), a primeira da América do Sul a ser criada separadamente das Escolas de Belas Artes ou Politécnicas, em 1930, ou seja, em pleno Movimento Moderno. Em 1952 concluiu o curso de Urbanismo, obtendo o grau de doutor 
60. Castriota (2013, p. 78).

61. Cf. Brasileiro (2008).

62. Originalmente apresentado no Primeiro Seminário de Estudos Mineiros, na Universidade de Minas Gerais, em 1956 e republicado em Vasconcellos (1983 [1956], p. 35-61).

63. Vasconcellos (1983 [1956], p. 37).

64. Ibid.

65. Ibid., p. 39.

66. Ibid., p. 41.

67. Ibid., p. 43-44. no ano seguinte, com tese sobre a arquitetura residencial em Ouro Preto. Sua produção arquitetônica "inclui inúmeras residências unifamiliares, prédios verticais, como o Edifício Mabe, e edifícios institucionais importantes, como a sede do Diretório Central dos Estudantes da Universidade de Minas Gerais". 60 Lecionou a disciplina Arquitetura no Brasil na própria UFMG entre 1948 e 1969, dirigindo a Escola de Arquitetura entre 1936 e 1964.61

Dentre seus principais textos destacam-se Vila Rica: Formação e Desenvolvimento (1956), Arquitetura no Brasil: sistemas construtivos (1961) e Construções Coloniais em Minas Gerais (1956),62 este que será agora objeto de análise, atendo-se à sua "Arquitetura Residencial".

Ainda na apresentação do texto, Vasconcellos (1983) estabelece algumas premissas básicas, cabendo destacar sua afirmação pela ausência de uma arquitetura brasileira, e sim uma arquitetura implementada pelos portugueses de acordo com o disponível no novo ambiente brasileiro, conferindo-lhe "o caráter de luso-brasileira". 63 Destaca também a presença portuguesa sendo muito mais marcante e transformadora do território brasileiro, especificamente de Minas Gerais, em oposição à tão divulgada migração paulista naquele estado. Segundo Vasconcellos, mesmo tendo os paulistas desbravado o território mineiro, não o consolidaram; não se fixavam por muito tempo em certa área, estavam sempre em busca de ouro; já os portugueses, "menos afoitos, se contentavam com o disponível certo, acomodando-se mais à nova terra que tantas promessas oferecia". ${ }^{64}$

Ainda na introdução, citando indiretamente a arquitetura eclética, Vasconcellos esboça uma crítica: "Mundanismo muitas vezes exagerado e decorrente do novo gosto, racionalizado, no século XIX, mas que de fato aflora da ostentação, do luxo e dos arranjos 'irreais' originados do renascimento mas aplicados com intuitos absolutamente diversos". ${ }^{65}$

Já com relação à arquitetura residencial propriamente dita, o arquiteto esboça o que chama de "evolução", 66 assim como fez Lucio Costa. Descreve a composição da casa urbana, mas demonstra ênfase e peculiar interesse na relação que estabelece entre a arquitetura rural colonial e aquela modernista, em Minas Gerais.

Ergue-se a construção sobre esteios de madeira, pelo menos na sua parte da frente, ficando a posterior ao nível do terreno, solução permitida pelos aclives naturais que não se corrigem. A varanda interessa a quase toda a fachada cuja composição se define no ritmo de seus apoios verticais repetidos [...] Aliás, as casas de fazendas mineiras são amplas em todos os sentidos, esparramadas nos terrenos, com grandes peças largamente ventiladas e iluminadas, sejam quarto, salas ou varandas [...] A parte baixa da construção não se fecha por paredes. Quando muito, com balaústres de secção quadrada postos losangularmente $[\ldots]^{67}$ 
E conclui que, "plasticamente desataviadas e singelas, mas agenciadas em boas proporções, harmonicamente dispostas", a arquitetura doméstica conforma

composições claras, limpas, definidas, bem moduladas e rítmicas, ostentando uma saúde plástica perfeita no dizer de Lucio Costa. Se lhes falta a ênfase que civilizações mais apuradas conferiram às suas moradias, será exatamente nesta despretensiosa beleza, nesta fisionomia não maquilada, que devemos buscar seu valor e importância. Aliás, não é outro o caminho que vem presidindo as melhores realizações da nossa arquitetura contemporânea. ${ }^{68}$

Comparando-as às palavras de Lucio Costa:

É nas suas aldeias, no aspecto viril das suas construções rurais a um tempo rudes e acolhedoras, que as qualidades da raça se mostram melhor. Sem o ar afetado e por vezes pedante de quando se apura, aí, à vontade, ela se desenvolve naturalmente, adivinhando-se na justeza das proporções e na ausência de "make-up", uma saúde plástica perfeita - se é que podemos dizer assim. ${ }^{69}$

Discursos semelhantes a arquitetos contemporâneos em prol de uma arquitetura fundadora e outra revolucionária. Costa e Vasconcellos adotam o "viés estético, derivado de uma visão historiográfica bastante específica". ${ }^{70} \bigcirc$ mais peculiar do texto de Vasconcellos, no que tange a esta pesquisa, é o croqui que o acompanha (figura 8), no qual estabelece relação direta entre a composição da edificação rural mineira a uma típica edificação onde se fazem presentes os cinco pontos da "nova arquitetura", em especial o emprego de pilotis, liberando o espaço do pavimento térreo, e a fachada com grandes aberturas. A conclusão do texto também dá o tom modernista ao destacar a ausência de ornamentos, a "fisionomia não maquilada"71 como pistas e diretrizes do século XVIII deixadas a serem redescobertas na "arquitetura contemporânea". ${ }^{72}$

Ao classificar a arquitetura produzida entre fins do século XIX e início do $X X$ como um "hiato entre o colonial e o modernismo", ${ }^{73}$ ainda mais vivendo em uma cidade como Belo Horizonte, que já nasceu eclética, foi como chefe do Iphan em Minas que Vasconcellos consolidaria seu pensamento e sua visão acerca do que valia a pena preservar. Respaldado por Rodrigo Melo Franco de Andrade, consolidou as primeiras ações efetivas em torno da preservação de Ouro Preto, e, obviamente, do casario colonial.
69. Costa (1937, p. 31).

70. Castriota (2013, p. 80).

71. Vasconcellos (1983 [1956], p. 44).

72. Ibid.

73. Brasileiro (2008, p. 3). 
74. Cf. Bicalho; Brandão; Oliveira (2006).

75. Cf. Brasileiro (2008)
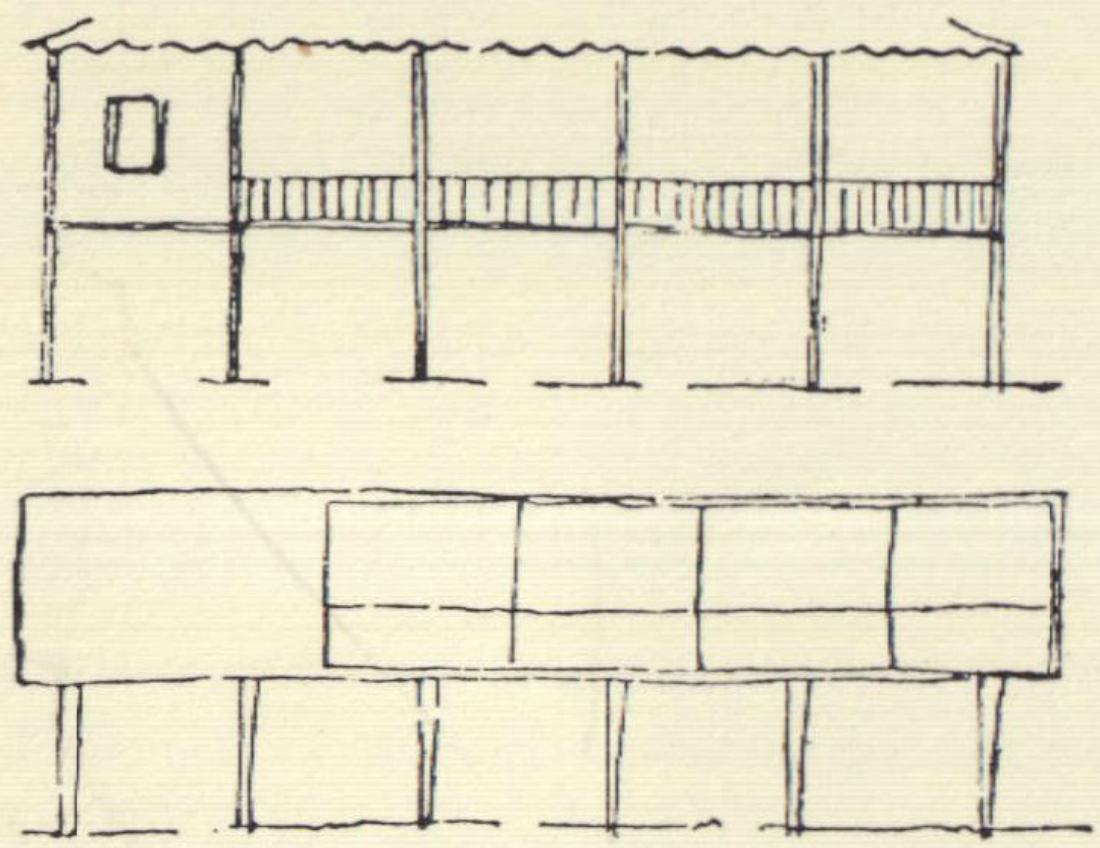

Figura 8 - Desenho de Sylvio de Vasconcellos, relacionando os partidos da arquitetura rural setecentista e da modernista. Fonte: Vasconcellos, 1983 [1956], p. 43.

Ainda, ao considerar a cidade como expressão estética, as intervenções de Vasconcellos visavam restabelecer a visão de conjunto, principalmente ao olhar distante, do panorama central dos núcleos considerados históricos. Atacou veementemente o ecletismo e suas platibandas e ornamentos, respaldando-se em Lucio Costa. Ao recriar, ao seu modo, a prática da restauração, sistematizou as ações e as replicou por entre as cidades com conjuntos setecentistas tombados nacionalmente no estado. Pode-se dizer, dessa forma, que o Sylvio intelectual complementava na prática o Sylvio gestor do patrimônio. ${ }^{74}$

Em 1964, em plena ditadura, foi afastado da Escola de Arquitetura da UFMG. Mudou-se para o Chile, onde lecionou na universidade local. Retornou ao Brasil tempos depois ao ser absolvido do inquérito, retomando as aulas na UFMG, por breve período, até ser aposentado compulsoriamente pelo Ato Institucional $\mathrm{n}$. 5. Exilou-se, assim, nos Estados Unidos a partir de 1969, atuando como Especialista em desenvolvimento urbano nas Organizações dos Estados Americanos, em Washington e na Cidade do México. Morreu no exílio em 1979.75 
Sua vasta atuação dentro do Iphan foi vital na conformação do núcleo tombado atual de São João del-Rei, e suas instruções, seguidas sempre à risca, explicitaram o conjunto pseudocolonial das cidades mineiras. Mas este é um assunto para uma próxima discussão.

\section{CONSIDERAÇÕES FINAIS}

patrimônio, nos 30 primeiros anos de sua atuação, insinuou a escravidão da personalidade - ao selecionar um período da historiografia como o único válido e aceitável à preservação -, em cujo assunto nenhum teórico ou historiador da arquitetura poderá se furtar a reconhecê-lo. $\bigcirc$ valor artístico, tão preconizado por Costa ao elaborar os pareceres de tombamento de bens imóveis, era vetado em novas edificações em prol da valorização e do destaque da arte do passado. E ainda hoje, em decorrência das diretrizes tão consolidadas pelo Iphan nas aprovações de reformas e novas construções nas cidades tombadas ao longo do século XX, a replicação em "estilo patrimônio"76 ainda persiste, muitas vezes camuflada nos critérios dos conselhos municipais de patrimônio, criados a partir da década de 1980, como estabeleceu a Constituição.

Além de configurar um perfil urbano excludente e sem pluralidade, o fazer arquitetônico contemporâneo (plástico, tecnológico e estrutural) se perde nessa busca equivocada pela preservação. Arquitetos privam outros arquitetos de projetar de acordo com seu tempo. Já está mais do que comprovado que arquiteturas de tempos diferentes podem coexistir no mesmo ambiente, aliás, é apenas essa coexistência que explicita e enfatiza a história e as transformações de uma sociedade. Uma obra de arte sendo copiada, em dias que correm, significa desvalorização, desmoralização e má-fé. Quem constrói hoje não está imbuído do espírito e sentimento dos mestres de obras e construtores dos séculos passados.

As práticas desenvolvidas pelo Iphan em suas primeiras décadas estiveram permeadas por posturas autoritárias. Embora esse posicionamento venha sendo criticado já há algum tempo, sabe-se que ainda existe. Uma das implicações da ampliação da concepção de patrimônio cultural é exatamente a crítica à autonomia e autoridade do saber técnico na seleção e valorização de bens culturais. A introdução do entendimento de que quem deve atribuir valor aos bens são as comunidades às quais eles estão inseridos poderá assegurar, num futuro próximo, cidadãos com uma melhor relação de pertencimento com seu patrimônio histórico e artístico. 
As possibilidades históricas existentes nas arenas políticas também devem ser consideradas nas ações dos sujeitos destacados nesta pesquisa, que às vezes se revestem de grande autonomia, como se fossem manipuladores de todo aquele processo. A atuação de tais agentes foi possibilitada por um momento histórico determinado que tornou certo grupo de modernistas agentes do Estado, com a incumbência de definir o caráter, o escopo e a fisionomia daquilo que deveria ser patrimônio nacional. O Iphan conseguiu se estabelecer como um órgão estatal com competência legal, com muito êxito, aliás.

Evidencia-se a ação humana, social e historicamente determinada, na delimitação do patrimônio digno de ser inserido na memória nacional e, consequentemente tudo aquilo que deve ser fadado ao esquecimento. Considera-se, assim, que a ação do órgão federal de proteção ao patrimônio legitima algo inventado.

Assim, a política conduzida pelo Iphan entre 1937 e 1980 consolidou a desconsideração da importância cultural da arquitetura eclética, com consequências que perduram até hoje, evidenciadas nas descaracterizações e demolições de prédios representantes da arquitetura brasileira. As propostas e as estratégias de preservação advindas do órgão estiveram - e, muitas vezes, ainda estão - desligadas do processo histórico de transformação urbana, negando aspectos intrinsecamente relacionados à história dessas localidades e construindo arbitrariamente modelos a serem seguidos e preservados. 


\section{REFERÊNCIAS}

ARQUIVOS CONSULTADOS

Arquivo Central do Iphan (ACI/RJ) no Rio de Janeiro. Assunto: Ouro Preto - Série Obras: Caixas 0218, 0246, 0247. Assunto: Rio de Janeiro - Série Inventário: RJ/264/3, RJ265/1. Assunto: São João del-Rei - Série Inventário: Caixas MG129/1, MG129/2, MG129/3, MG131/3; Série Personalidades: Alcides da Rocha Miranda, Arthur Arcuri, Augusto Carlos da Silva Telles, José de Souza Reis, Lucio Costa, Sylvio de Vasconcellos; Série Obras: Caixas 0277, 0278, 0279, 0280, 0281, 0282, 0283, 0284, 0285, 0288, 0291, 0295, 0296, 0297, 0298, 0299, 0300, 0301; Série Tombamento: Processo 0068-T38, Processo 0361-T-46, Processo 1185-T-85, Processo 373-T-47; Série Cartografia: ANS01543, ANS 1544, ANS01564, ANS01566, ANS01568, ANS01569, ANS01579, ANS01580, ANS01581.

FONTES MANUSCRITAS

ANDRADE, Rodrigo Melo Franco de. [Correspondência]. Destinatário: Benedito Saraiva, diretor do Liceu de Artes e Ofícios de Ouro Preto. S./d.; s./p. ANJOS. C.A.V. O liceu de artes e oficios: uma história que se reconstrói. 1998.

ANJOS. C.A.V. O liceu de artes e ofícios: uma história que se reconstrói. 1998.

COSTA, Lucio. Informação s/nº. Rio de Janeiro, 10 maio 1954a. ACI/RJ - Série Obras, Caixa 0218 , Pasta 0946.

COSTA, Lucio. Informação ${ }^{\circ}$. 247. Comunicação com José de Souza Reis e Renato Soeiro. Rio de Janeiro, 29 dez. 1954b. ACI/RJ - Série Obras, Caixa 0218, Pasta 0946.

COSTA, Lucio. Informação n ${ }^{\circ}$. 84. Comunicação com José de Souza Reis. Rio de Janeiro, 29 maio 1956. ACI/RJ - Série Obras, Caixa 0218, Pasta 0946.

COSTA, Lucio. Processo de Tombamento do prédio do Ministério da Agricultura, no Rio de Janeiro. Arquivo Central do Iphan (ACI/RJ) no Rio de Janeiro, Série Tombamento, Processo n ${ }^{\circ}$. 982-T-78, de 1978.

VASCONCELLOS, Sylvio de. Ofício nº 500. Belo Horizonte, 26 jun. 1958. ACI/RJ - Série Obras, Caixa 0218, Pasta 0946. 
BRANDI J. Liceu de Artes e Ofícios de Ouro Preto em 1898. 1. Fotografia. Arquivo Público Mineiro, s/d. Disponível em: <https://bit.ly/2jWdh0v>. Acesso em: 6 jun. 2019.

COSTA, Lucio. Croqui para remodelação da fachada do Liceu de Artes e Ofícios de Ouro Preto. 1956. ACI/RJ - Série Obras, Caixa 0218, Pasta 0946.

LICEU de Artes e Ofícios de Ouro Preto após as obras, já como cinema, na década de 1980. O Tempo, 2016. Disponível em: <https://bit.ly/2k1GN5c>. Acesso em: 6 mai. 2019.

LICEU de Artes e Ofícios de Ouro Preto em fase final das obras para cinema, com grande volume na parte posterior; e a solução encontrada por Vasconcellos com a construção de um segundo pavimento em estilo patrimônio na edificação vizinha, em 1959. 1. Fotografia. ACI/RJ - Série Obras, Caixa 0218, Pasta 0946.

LIVROS, ARTIGOS E TESES

ANDRADE, Rodrigo Melo Franco de. Palestra proferida em Ouro Preto, a 1-7-68. Revista do Patrimônio Histórico e Artístico Nacional. Rio de Janeiro: Ministério da Educação e Saúde; Serviço do Patrimônio Histórico e Artístico Nacional, n. 17, p. 11-26, 1969.

BAETA, Rodrigo Espinha. A crítica de cunho Modernista à arquitetura colonial e ao Barroco no Brasil: Lucio Costa e Paulo Santos. Cadernos de Arquitetura e Urbanismo, Belo Horizonte, v. 10, n. 11, p. 35-56, 2003.

BAREL FILHO, Ezequiel. Lucio Costa em Ouro Preto: a invenção de uma "cidade barroca". Dissertação (Mestrado em História) - Faculdade de Letras, Universidade de Coimbra, Coimbra (PT), 2013.

BICALHO, Carlos H.; BRANDÃO, Mariana G.; OLIVEIRA, Françoise G. Conjunto Arquitetônico Sylvio de Vasconcellos. Belo Horizonte: Prefeitura Municipal de Belo Horizonte, 2006.

BRASILEIRO, Vanessa Borges. Sylvio de Vasconcellos: um arquiteto para além da forma. Tese (Doutorado em História) - Faculdade de Filosofia e Ciências Humanas, Universidade Federal de Minas Gerais, Belo Horizonte, 2008. 
BUENO, Fernanda Alves de B.; SCHETTINO, Patrícia T. J.; PASCOAL, Gabriela S.; RIBEIRO, Paula. Reflexão sobre a produção arquitetônica em Ouro Preto da segunda metade do séc. XIX ao início do séc. XX: reconhecimento e preservação. In: Encontro Internacional sobre Preservação do Patrimônio Edificado - Arquimemória, V, 2017, Salvador, Anais [...]. Salvador: IAB-BA; UFBA, 2017.

CASTRIOTA, Leonardo Barci. Os alvos da história da arquitetura: João Boltshauser e Sylvio de Vasconcellos. Arquiteturarevista, São Leopoldo (RS), v. 9, n. 2, p. 73-81, jul./dez. 2013.

CASTRIOTA, Leonardo Barci. Patrimônio Cultural: conceitos, políticas instrumentos. São Paulo: Annablume, 2009.

COMPAGNON, Antoine. Os cinco paradoxos da modernidade. Belo Horizonte: UFMG, 1996. COSTA, Lucio. Documentação necessária. Revista do Serviço do Patrimônio Histórico e Artístico Nacional, Rio de Janeiro: Ministério da Educação e Saúde; Serviço do Patrimônio Histórico e Artístico Nacional, n. 1, p. 31-39, 1937.

COSTA, Lucio. Lucio Costa: sôbre arquitetura. Porto Alegre: Centro de Estudantes Universitários de Arquitetura, 1962.

COSTA, Lucio. Problema Mal Posto. 19 de novembro de 1972. PESSOA, José (Org.). Lucio Costa: Documentos de trabalho. Rio de Janeiro: Iphan/Minc, p. 278, 1999.

CHUVA, Márcia R. R. Os Arquitetos da Memória: sociogênese das práticas de preservação do patrimônio cultural no Brasil (Anos 1930-1940). Rio de Janeiro: Editora UFRJ, 2009.

DIAS, Diego Nogueira. "Estilo" Patrimônio: formação e consolidação de uma identidade nacional em São João del-Rei, Minas Gerais. Dissertação (Mestrado em Ciências em Arquitetura) - Faculdade de Arquitetura e Urbanismo, Universidade Federal do Rio de Janeiro, Rio de Janeiro, 2019.

FONSECA, Maria Cecília Londres. O patrimônio em processo: trajetória da política federal de preservação no Brasil. Rio de Janeiro: Editora UFRJ/Minc-Iphan, 2005.

GUIMARAENS, Cêça. Paradoxos entrelaçados: as torres para o futuro e a tradição nacional. Rio de Janeiro: Editora UFRJ, 2002.

MICELLI, Sergio. SPHAN: Refrigério da Cultura Oficial. Revista do Patrimônio Histórico e Artístico Nacional, Rio de Janeiro: SPHAN; pró-Memória, n. 22, p. 44-47, 1987. 
NASCIMENTO, Flávia Brito do. Patrimônio Cultural e escrita a história: a hipótese do documento na prática do Iphan nos anos 1980. Anais do Museu Paulista, São Paulo, v. 24, n. 3, p. 121-147, set.-dez. 2016.

PUPPI, Marcelo. Por uma História não Moderna da Arquitetura Brasileira: questões de historiografia. Campinas: Pontes, 1998.

REIS, Luiz Fernando. O feito e o efeito: as memórias e as representações da preservação do Conjunto Arquitetônico e Urbanístico do Sêrro - MG. Tese (Doutorado em Arquitetura) - Faculdade de Arquitetura e Urbanismo, Universidade Federal do Rio de Janeiro, Rio de Janeiro, 2012.

RUBINO, Silvana. Lucio Costa e o patrimônio histórico e artístico nacional. Revista USP, São Paulo, n. 53, p. 6-17, 2002.

RUBINO, Silvana. O mapa do Brasil Passado. Revista do Patrimônio Histórico e Artístico Nacional, Rio de Janeiro: Ministério da Educação e Saúde; Serviço do Patrimônio Histórico e Artístico Nacional, n. 24, p. 97-105, 1996.

SAIA, Luís. Artigo sem título publicado na revista Arquitetura, n ${ }^{\circ}$. 17, em 1977. Proteção e Revitalização do Patrimônio Cultural no Brasil: uma trajetória. Brasília: SPHAN/pró-Memória, p. 17-?, 1980. Disponível em: <https://bit.ly/2GZTyUt>. Acesso em 30 de dezembro de 2018.

SILVA, Lucílio Luís. Educação e trabalbo para o progresso da nação: o Liceu de Artes e Ofícios de Ouro Preto (1886-1946). Dissertação (Mestrado em Educação Tecnológica) Centro Federal de Educação Tecnológica de Minas Gerais, Belo Horizonte, 2009.

VASCONCELLOS, Sylvio de. Arquitetura no Brasil: sistemas construtivos. Belo Horizonte: UFMG, 1979.

VASCONCELLOS, Sylvio de. Construções Coloniais em Minas Gerais. Arquitetura dois estudos. Goiânia: MEC/SESU/PIMEG-ARQ/UCG, p. 37-61, 1983.

VASCONCELLOS, Sylvio de. Vila Rica: Formação e Desenvolvimento. São Paulo: Perspectiva, 2011.

Artigo apresentado em 13/09/2019. Aprovado em 05/02/2020. (cc) BY

All the contents of this journal, except where otherwise noted, is licensed under a Creative Commons Attribution License 